\title{
The contribution of benefit-in-kind taxation policy in Britain to the 'Peak Car' phenomenon
}

By: Scott Le Vine (Imperial College), Peter Jones (University College London), and John Polak (Imperial College)

Submitted to: Phil Goodwin and Gordon Stokes, editors of Transport Reviews special issue on 'Peak Car'

Submission date: 1 January 2013

Revision:

$1^{\text {st }}$ Revision, 26 March 2013

\begin{abstract}
Car use per person has historically grown year-on-year in Great Britain since the 1950s, with minor exceptions during fuel crises and times of economic recession. The 'Peak Car' hypothesis proposes that this historical trend no longer applies, so that future traffic growth will be limited to increases in national population. The British National Travel Survey provides evidence of such an aggregate levelling off in car mileage per person since the mid 1990s, but further analysis shows that this is the result of counter trends netting out: in particular, a reduction in per capita male driving mileage being offset by a corresponding increase in female car driving mileage. The main contributory factor to the decline in male car use has been a sharp reduction in average company car mileage per person. The paper investigates this aspect in more detail.
\end{abstract}

Use of company cars fell sharply in Britain from the 1990s up to the 2008 recession. Over the same period, taxation policy towards company cars became more onerous, with increasing levels of taxation on the benefit-in-kind value of the ownership of a company car, and on the provision of free fuel for private use. The paper sets out the changes in taxation policy affecting company cars in the UK, and looks at the associated reductions in company car ownership (including free fuel) and patterns of use. It goes on to look in more detail at which groups of the population own company cars and in which parts of the country they are most used, and how these patterns have changed over time. A preliminary investigation is also made of possible substitution effects between company car and personal car driving, and between company car use and rail travel.

Clearly, the role of the company car is only one of many factors that are contributing to aggregate changes in levels of car use in Great Britain, alongside demographic changes and a wide range of policy initiatives. But, company car use cannot fall below zero, so the effect of declining year-on-year company car mileage suppressing overall car traffic levels cannot continue indefinitely. 


\section{Introduction}

\subsection{Factors contributing to the 'Peak Car' phenomenon}

The 'Peak Car' hypothesis - that the level of car travel per person has stabilised - has stimulated an important and overdue debate amongst transport researchers, as it is challenging long-held assumptions about the drivers behind the growth in car use and spurring research into possible causes that lie outside the traditional areas of focus (Goodwin 2012a). The 'Peak Car' debate covers both factual observations of car usage trends in the past, with the levelling off first noticeable in some places in the 1990s (Metz 2012), and a forward-looking element as to what this means for future road traffic forecasts: whether car usage will once again grow, remain stable, or decline.

BITRE (2012) looks at cross-national trends in car usage in many countries around the world, and hypothesises that in each case there is a long-term trend towards saturation in car driving mileage per capita (at different levels in different countries), with deviations on the trajectory towards the country-specific saturation levels being due to standard economic factors such as unemployment and fuel prices.

Others have looked at changes in driving by population sub-group. Kuhnimohof et al. (2012) show that in demographic terms it is young adults, particularly young men, whose car driving has fallen the most since the 1990s. Metz suggests that demographic change - specifically aging and population growth - will be the 'main determinant of future travel demand' in developed countries (Metz 2012.)

It is widely speculated that telecommunications technologies - particularly mobile ones (Goodwin 2012b) - may reduce physical mobility, as they allow people to perform many activities remotely that otherwise would require physical mobility. Similarly, universal access to broadband internet service can be expected to affect mobility, though there is considerable uncertainty about whether the net effects of such technologies will be to encourage reductions in travel; it is also plausible that they may stimulate certain types of travel by increasing the ability to develop [long-distance] personal or business relationships (van den Berg et al. 2013).

Le Vine and Jones (2012) look in detail at the trends in car use over time of different demographic and geographical groups in Great Britain. They conclude that the observed aggregate levelling of in car driving per adult is the net effect of a variety of trends moving in different directions: car use in the Greater London area has been declining, while it has continued to grow rapidly in rural areas; younger people are driving less while older people are driving more (due to a cohort ageing effect); and male driving is reducing while female driving is increasing. One unique finding of this study was that the main factor accounting for the reduction in male car mileage, among those aged between 30 and 60, was a sharp reduction in company car use. It found that, whilst company cars have never accounted for more than a tenth of Britain's car stock, they contribute disproportionately to overall traffic levels; and that changes in fiscal policy affecting company cars have been associated with reductions in company car use that have had a major impact on overall car traffic levels.

This paper explores in more detail the role of company car use in contributing to the decline in male car driving in Great Britain over the past two decades - as one component of the 'Peak Car' phenomenon. 


\subsection{Data and analysis methods}

The main data set used in this paper is the British National Travel Survey (Rofique et al. 2011), which was collected from the 1960s to the 1980s on an ad-hoc annual basis and has since 1988 been a continuous survey. During the 1990s the NTS had an annual sample size of approximately 3,500 respondent households drawn from across Great Britain; this was increased from 2002 onwards to around 9,000 households. The data comes primarily from two sources: a household interview in which demographic, vehicle ownership and other questions are asked, and a week-long selfcompletion diary recording each household member's travel.

In this paper the term 'company car' refers to a car that is owned by an employer (or a specialist third-party firm that leases the car to the employer) and made available to an employee on a continuous basis for their business and private use, as part of their remuneration package. A company car is a 'benefit-in-kind' that is received in addition to salary but treated advantageously in the tax code. Nearly three in five (59\%) new cars in Britain are initially registered to a corporate entity (including both private- and public-sector organisations) rather than a person (DfT 2012a). However, the majority of corporately-purchased cars are not 'company cars' as defined here and are instead used in other ways (e.g. as pool cars for exclusively business use, or hire cars).

In this paper we also refer to 'personal' and 'non-household' cars. The personal car class includes cars that are owned by the driver or another adult living in their household, as well as light vans and land rovers/jeeps, as in the latter two cases their ownership status (company or personal) is not collected in the NTS. Table 1 shows the breakdown of driving mileage within this category by type of vehicle; car-body-styles are responsible for over $90 \%$ of the mileage in this category, though this proportion has fallen over time whilst the land rover/jeep sub-group has increased. The nonhousehold car category includes cars/vans/land rovers/jeeps that are neither personal cars nor company cars (in the sense defined above).

Car-body-styles
privately)

$\begin{array}{lll}1995 / 7 & 95 \% & 2 \% \\ 2000 / 2 & 94 \% & 2 \% \\ 2005 / 7 & 92 \% & 5 \% \\ 2008 / 10 & 92 \% & 5 \%\end{array}$

\section{Light van-body- $\underline{\text { style }}$ (company/personal status unknown)} body-style (company/personal status unknown)

$\begin{array}{ll}3 \% & 100 \% \\ 4 \% & 100 \% \\ 3 \% & 100 \% \\ 3 \% & 100 \%\end{array}$

Table 1: Breakdown in 'personal car' driving mileage by vehicle body style

Three methodological points constrain the analysis reported here. First, prior to 1995 the NTS data cannot be weighted for direct comparison to the 1995-onwards time series, and so have been excluded from this analysis. Second, to ameliorate the effects of small sample sizes once the data are further disaggregated into detailed cross-tabulations, results in the remainder of this paper are presented in the following year groups: 1995/7 (10,597 participating households), 2000/2 (16,339 households), 2005/7 (27,992 households), and 2008/10 (26,827 households). Third, there is a discontinuity in the background data, due to the effects of the recession beginning in 2008 and the 
subsequent continuing economic stagnation. So, in some cases we observe breaks in trend in the most recent 2008/10 data point.

The remainder of this paper is structured as follows. Section two examines how the tax treatment of company cars in the UK has changed over time. Section three looks at the broad reductions in company car use among men, and how this has affected overall car use. Section four looks in more detail at changing patterns of ownership and use by occupational type and location, and Section five looks for evidence of substitution effects. Finally, section six concludes the paper with a discussion of the implications of these findings for long-term trends in personal mobility.

\section{Company car policy in the UK}

\subsection{Taxation charges}

Cars as an employee benefit first emerged in the UK as a means of providing staff with in-kind value that did not violate the wage freezes of the 1970s. Prior to the Finance Act of 1976 (with the relevant sections coming into effect in the 1977/8 tax year), the provision to an employee of a company car for private use attracted no tax liability (Great Britain 1976). From 1987/8 to 1993/4, company cars were taxed on the basis of age, engine size, and their original value when new. The 'scale charge' - the amount taxpayers were required to add to their taxable income - escalated rapidly year-on-year in the early 1990s: for a car under four years old with an engine size between 1.4 litres and 2.0 litres, the charge grew from $£ 1,031$ in $1987 / 8$ to $£ 3,226$ in $1993 / 4$, both quoted at 2010 prices (HMRC 2012a).

The scale charge also depended on how much the car was driven - the $18,000^{\text {th }}$ mile driven for business purposes led to an abrupt 50\% drop in taxation, providing a strong incentive for company car drivers to reach that threshold (HMRC 2012a).

From 1993/4 the system for company car ownership was revised, with the annual taxable amount now set at $35 \%$ of the car's original market value; engine size and age no longer affected it. But the tax incentives for driving high business mileage remained: the $35 \%$ charge fell by a third after the first 2,500 , and by two thirds after 18,000 miles. The system was updated again in 1999/2000, with the effect of reducing somewhat the tax incentives accruing from high business mileage, to a reduction of $29 \%$ after 2,500 miles and $57 \%$ after 18,000 miles (HMRC 2012b).

The system was more radically overhauled in the 2002/3 tax year, such that the charges now depended on the car's $\mathrm{CO}_{2}$ emissions band, with rates ranging from $15 \%$ for the lowest-emissions bands up to $35 \%$ for the highest per-mile emitters. Perhaps most importantly, the tax incentives for reaching specific mileage thresholds that had been in place since the 1980 s were removed entirely in 2002/3.

In more recent years, company car taxation policy has further incentivised lower-emitting cars, to the point that zero-emission cars (e.g. electric cars) have not been subject to any company car tax since 2010/11 (HMRC 2012b). In other words, company car policy once again provides large tax incentives for employers to compensate staff with vehicles (paid for by the employer) instead of salary, but in its contemporary form providing much stronger incentives for lower-emitting cars. 
Employers can also provide unlimited 'free' fuel to an employee for private use, with the staff member incurring only a fixed tax liability - an amount that is invariant with respect to the amount of fuel used. Thus, driving high mileages was further encouraged during the 1980s and 1990s, as having fuel paid for by the employer made financial sense only if enough fuel was consumed to justify the tax liability (the 'fuel scale charge').

The fuel scale charge increased rapidly from the late 1990s to the early 2000s (Figure 1), more than doubling (in real terms) from about $£ 1,400$ in $1997 / 8$ to $£ 3,600$ in 2001/2 (both in 2010 prices), for a petrol car with an engine size between 1.4 litres and 2.0 litres. By 2010/11 this had risen to $£ 4,500$.

Outside the UK company cars also receive favourable tax treatment (relative to monetary compensation) in many of the European Union's other major economies (Macharis and De Witte 2012), as well as some other OECD countries (CRA 2012). It has been estimated that the market distortion due to the favourable tax treatment of company cars in the European Union (if one accepts that it is an economic inefficiency) is equal to roughly a half per cent of EU-area gross domestic product (Naess-Schmidt and Winiarczyk 2009).

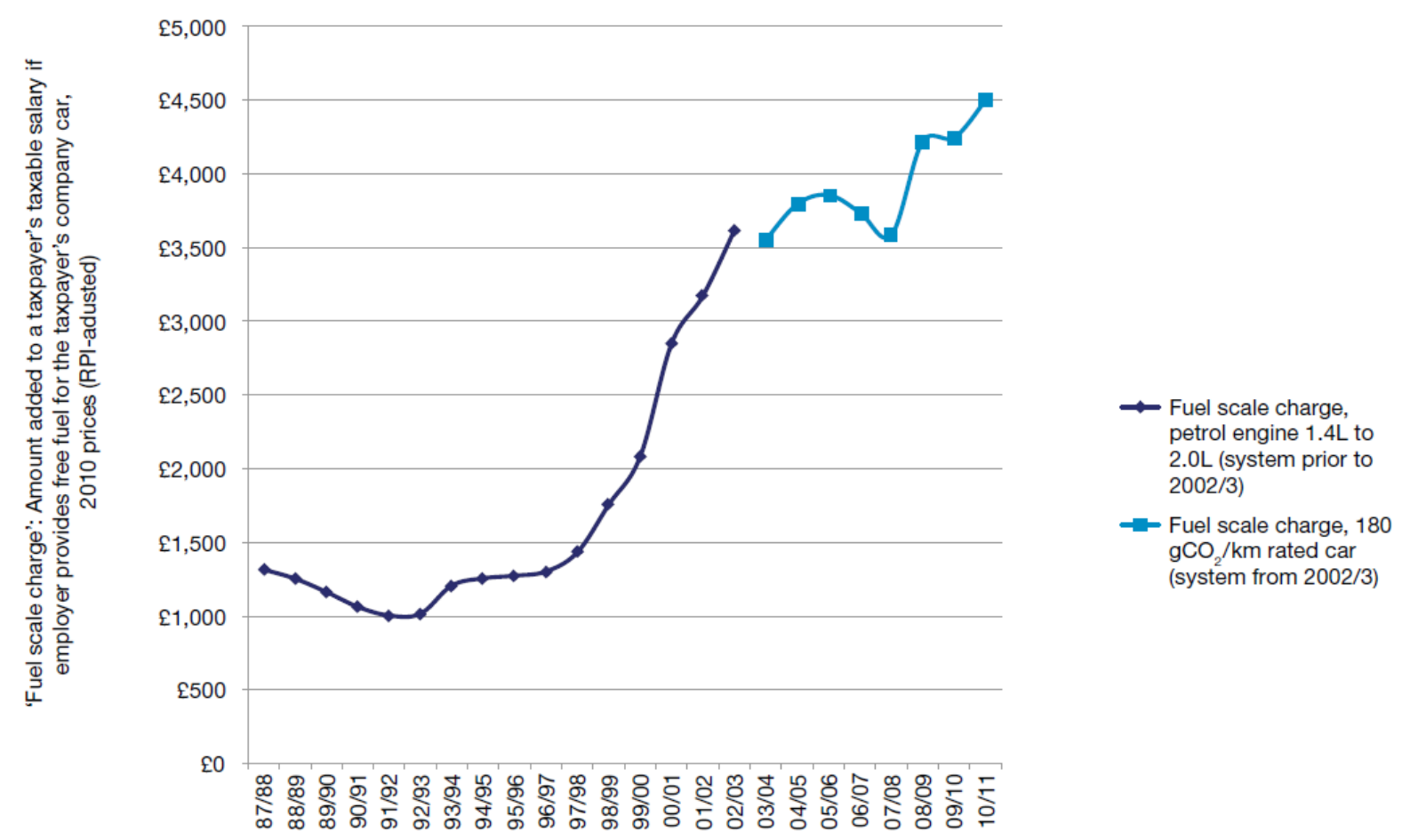

Figure 1: Changes over time in the fuel scale charge for receiving free fuel for personal use as a benefit-in-kind (HMRC 2012a) (reproduced from Le Vine and Jones 2012)

\subsection{Effects on provision of company cars}

In the 1995/96 tax year, approximately 1,650,000 UK tax payers reported having a company car on their tax return; by the $2009 / 10$ tax year, this had fallen to 970,000 - a drop of $41 \%$ from the $1995 / 6$ figure (HMRC 2012a). Figure 2 breaks this down further, into those just registering a company car and those also receiving free fuel; as can be seen, the rates of decline in the two cases are very different. 
Of the company car drivers registered with the tax authorities in 1995/6, around half (48\%, or 800,000 taxpayers) reported also receiving free fuel from their employer for their personal use. But by $2009 / 10$ this had dropped to $28 \%$ of all company car owners (270,000 taxpayers). The number of company car drivers not receiving free fuel fell by only $16 \%$, whilst the number of company car owners receiving free fuel for personal use dropped by $70 \%$.

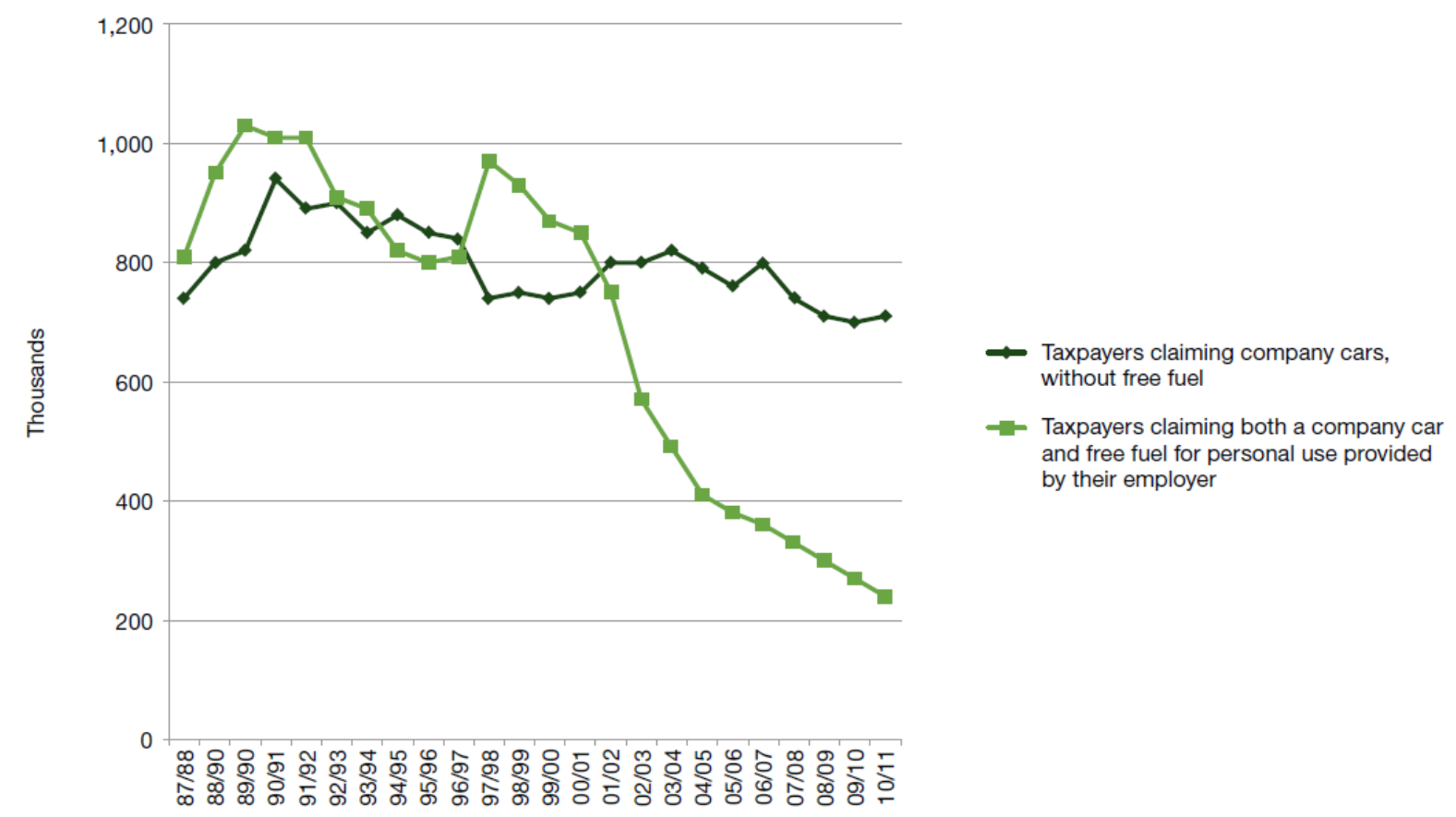

Figure 2: Number of taxpayers claiming a company car (with/without free fuel) as a benefit-in-kind, 1987/8 to 2010/11 (HMRC 2012a) (reproduced from Le Vine and Jones 2012)

\section{The contribution of company cars to overall car use in Great Britain}

Analysis of the NTS travel diary data shows that average driving mileage per capita in Great Britain levelled off in the late 1990s and then stayed essentially flat at around 3,700 miles/capita until a substantial fall with the onset of recession in 2008. The NTS data identifies the car that was driven on each occasion and classifies these as personal, company, or a non-household car. Figure 3 shows the breakdown of car driving by these three classes, on a per capita basis.

Here it can be seen that the overall stability in average car driving mileage per capita is the net result of a decrease in company car use and an increase in driving in personal cars. Were we only to analyse driving in personal cars, then we would not observe a clear 'Peak Car' effect prior to the recession.

In proportional terms, company car mileage per capita fell by $37 \%$ from $1995 / 7$ to $2005 / 7$ (averaging the three years), whilst personal car use grew by $10 \%$ over that period. Another important finding from Figure 3 is that there has not been any growth in the use of non-household cars, the category which includes employers' fleets of pool cars. So, there is no evidence of a large-scale shift from 
company cars that employees keep for their personal use to pool cars that they can use on a one-off basis for specific business-travel journeys. We investigate substitution issues further in section five, but note here that as the NTS is a repeated cross-sectional dataset we observe respondents only once (it is not a panel dataset). Respondents are also not asked whether they previously had a company car. Therefore it is not known whether people that previously had a company car have simply shifted to driving a personal car, and if so whether their overall driving mileage has changed.

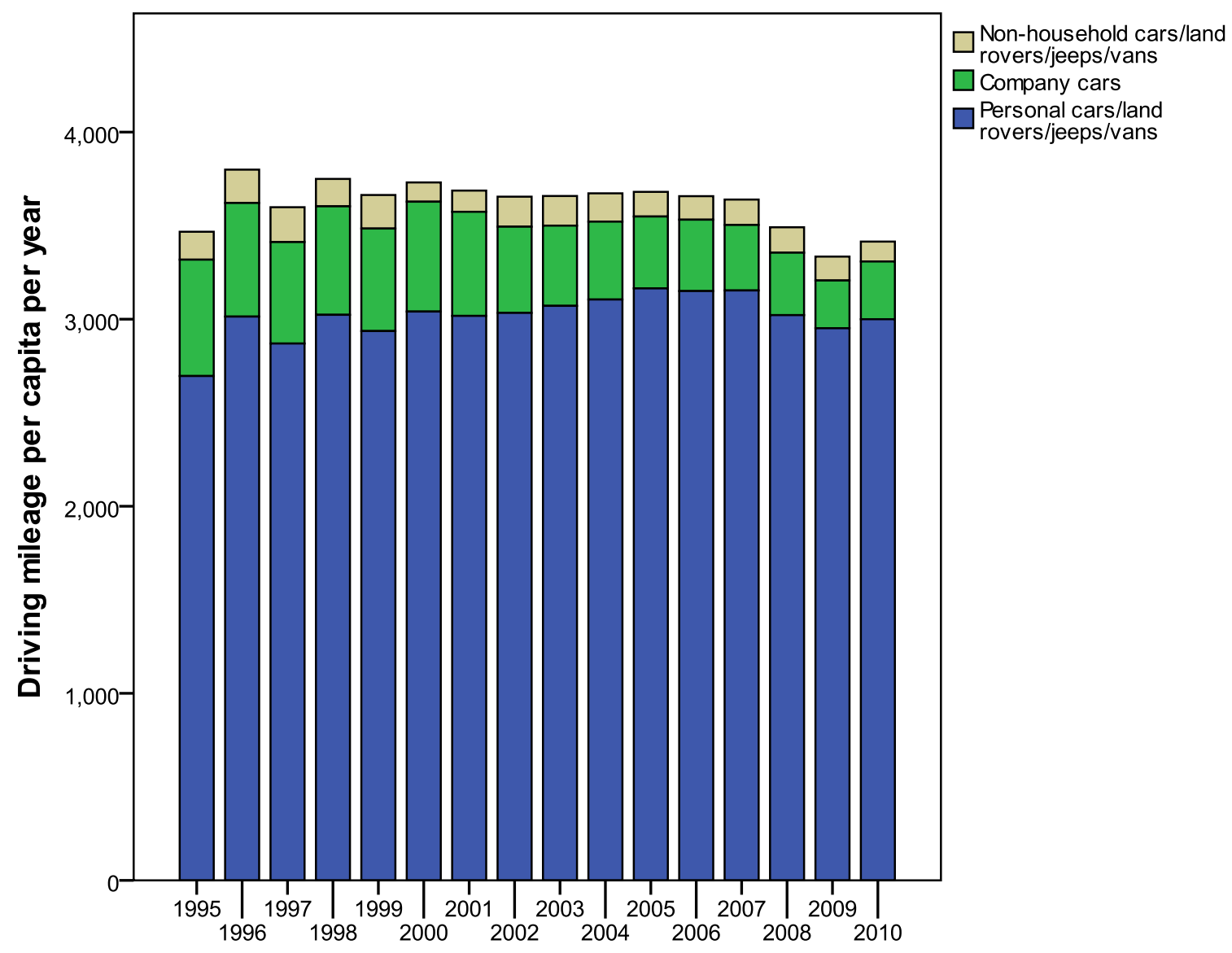

Figure 3: Trend in car driving mileage per capita by type of car ownership: personal car, company cars, and nonhousehold cars (reproduced from Le Vine and Jones 2012)

Table 2 shows that company car ownership has fallen 31\% on a per capita basis between 1995/7 and $2008 / 10$, whilst mileage per company car dropped $25 \%$. In other words, $55 \%$ the reduction in aggregate company car mileage is due to lower car ownership and $45 \%$ to less intensive use of each remaining company car; but this less intensive use of the fewer company cars is contrary to what might be expected. Over the same period, personal car ownership increased by $18 \%$, while average mileage fell about $11 \%$ on a per-car basis. The time trend for personal car mileage seems more logical: one would expect that the marginal car added to the car stock would be used less intensively than the existing fleet.

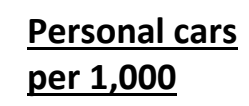

\section{Average driving mileage per personal \\ Company cars per 1,000}

\section{Average driving mileage per company}




\begin{tabular}{lrrrr} 
& population & \multicolumn{1}{c}{ car per year } & population & car per year \\
$1995 / 7$ & 390 & 7,228 & 29 & 20,460 \\
$2000 / 2$ & 426 & 7,102 & 29 & 17,111 \\
$2005 / 7$ & 458 & 6,868 & 23 & 15,909 \\
$2008 / 10$ & 462 & 6,444 & 20 & 15,341
\end{tabular}

Table 2: Car ownership disaggregated for personal and company cars

Figure 4 breaks down these aggregate net changes in personal and company car use into trends for different age groups by gender; note that this shows net changes for each age/gender group between 1995/97 and 2005/07 - excluding the effects of the recession.

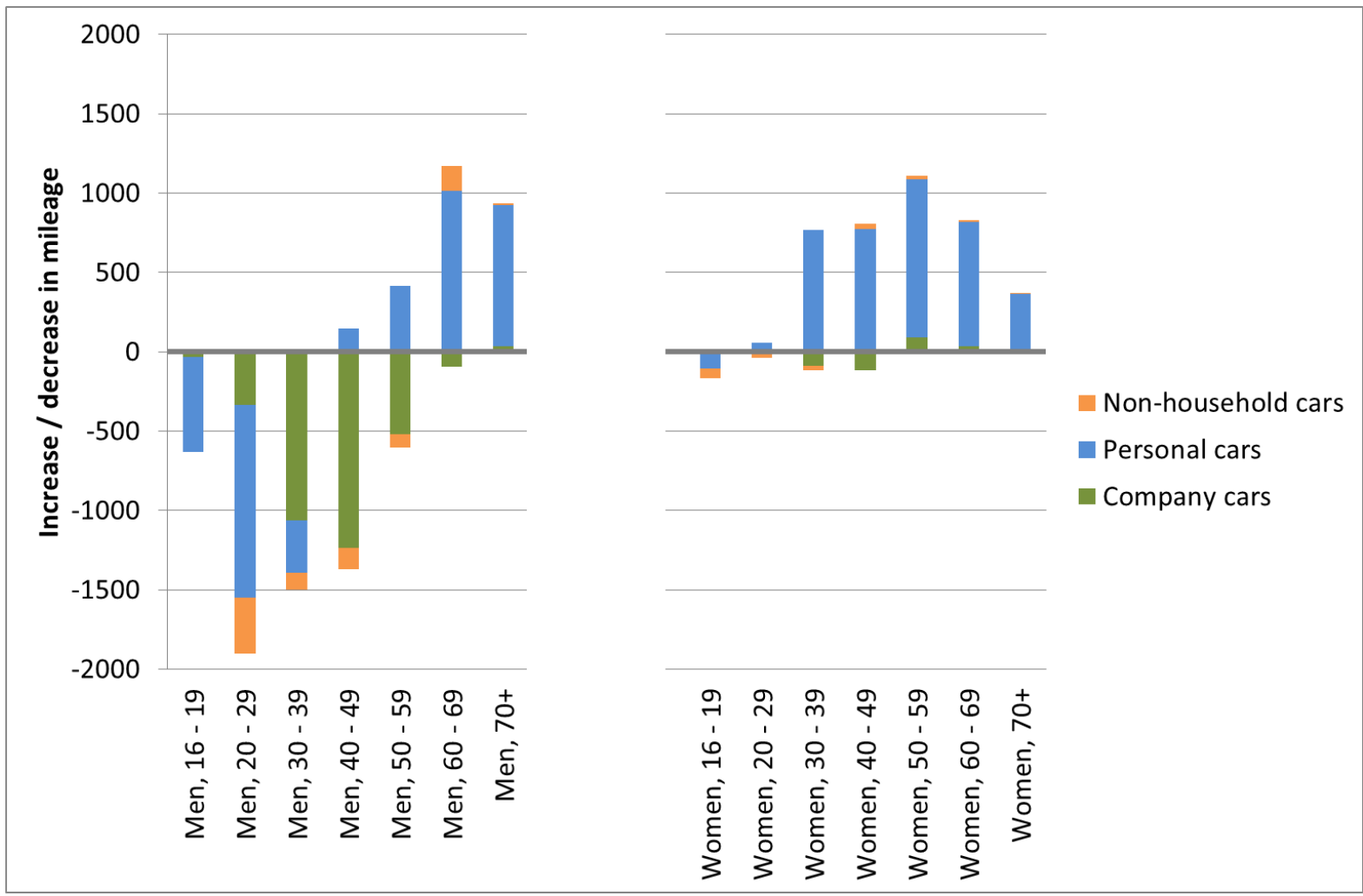

Figure 4: Trend in car driving mileage per capita by type of car and age/gender group (reproduced from Le Vine and Jones 2012)

Here we can see that women aged 30 and over have increased their average car use by around 800 miles per annum, almost entirely due to increases in personal car use. Conversely, men aged between 20 and 60 have reduced their car use, and for those aged between 30 and 60 , the vast majority of that reduction has been in company car mileage; men in their twenties have also substantially reduced their mileage in non-household cars.

Next, Figure 5 looks at changes in adult driving mileage per year over time, by personal income bands. First, averaged across all cars (left), and then distinguishing between personal cars (centre) and company cars (right). First looking at overall car use per adult, as expected there is a clear relationship between income and car driving mileage; however, we can observe a trend of reduced car driving over time among high-income people and a stabilisation or slight increase for lowerincome adults. The sharpest declines are amongst the highest income groups. 
This is contrary to what would normally be expected, and the reasons become clear when the data are disaggregated into personal and company car mileage (centre and right hand columns of Figure 5). Now it can be seen that most of the effect of falling mileage among high-income people can be accounted for by falling levels of company car usage. In 1995/7 43\% of mileage driven by people with personal incomes above $f 40,000 /$ year ( 2010 prices) was in company cars $(12,822$ miles overall, 5,529 in company cars); company car mileage declined sharply (by $60 \%$ ) to $23 \%$ of their driving mileage by $2005 / 7$ (9,984 overall, 2,253 in company cars). Over the same period, their personal mileage increased slightly (up $9 \%$, from 6,804 to 7,409 ), but the net effect was a $22 \%$ decline in average car mileage per adult amongst those earning more than $£ 40,000 /$ year.

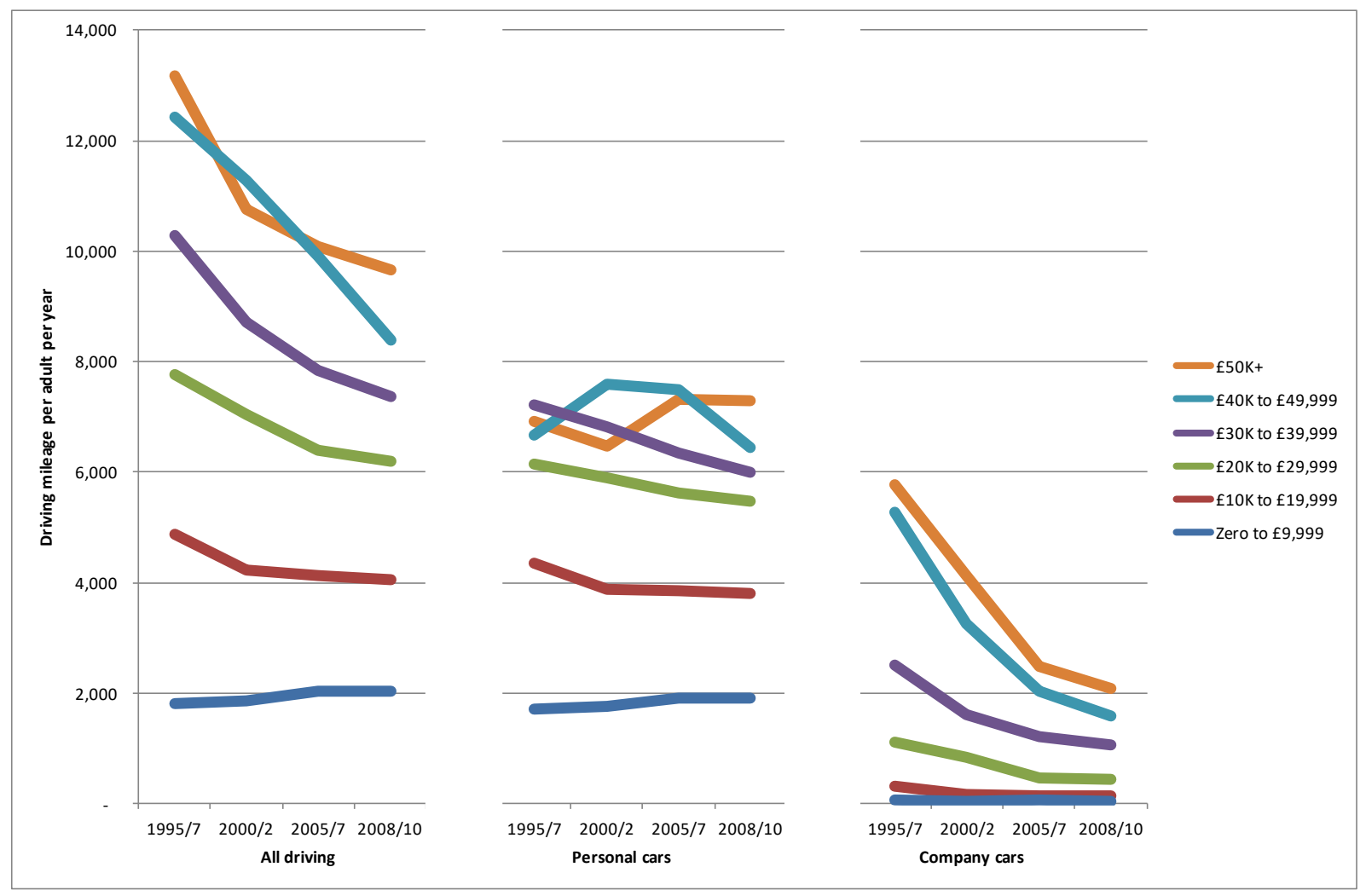

Figure 5: Trend in car driving mileage per capita by type of car ownership (left: all cars, centre: personal cars, right: company cars) and income band (reproduced from Le Vine and Jones 2012)

Company car use also fell for all the other income classes shown, an effect that decreases sharply moving down the income distribution. The rate of decrease for all income groups has slowed over time, particularly after 2005/7. Personal car use has declined since the mid-1990s for those in the $f 10,000$ to $f 39,999$ /year bands (by a weighted average of $9 \%$, from 5,322 to 4,853 miles per year), and up by $13 \%$ amongst people earning less than $f 10,000 / y e a r$, although from a very low base (up from 1,699 to 1,916 miles per year).

Table 3 shows that, in the NTS survey, average annual driving mileage for both types of company car provision - with and without free fuel - have fallen over the four time periods: by $17 \%$ for those claiming a company car and free fuel and $23 \%$ by those only having a company car. Company car drivers who also receive free fuel tend to drive more mileage in their company car ( $30 \%$ in $2008 / 10$ ). 
When disaggregated by journey purpose, the biggest 'mileage gap' between the two groups is in the distance driven for commuting, as opposed to other business mileage and driving for personal purposes.

\begin{tabular}{|c|c|c|c|c|}
\hline & & $\begin{array}{l}\frac{\text { Drivers of company cars }}{\text { not claiming 'free fuel' as }} \\
\frac{\text { a complimentary benefit- }}{\text { in-kind }}\end{array}$ & $\begin{array}{l}\frac{\text { Drivers of company cars }}{\text { claiming 'free fuel' as a }} \\
\frac{\text { complimentary benefit- }}{\text { in-kind }}\end{array}$ & $\begin{array}{l}\text { Difference, in } \\
\text { percentage terms }\end{array}$ \\
\hline \multirow{4}{*}{ Commuting } & $1995 / 7$ & 4,708 & 6,851 & $46 \%$ \\
\hline & $2000 / 2$ & 4,141 & 5,275 & $27 \%$ \\
\hline & $2005 / 7$ & 3,418 & 5,959 & $74 \%$ \\
\hline & $2008 / 10$ & 3,368 & 5,478 & $63 \%$ \\
\hline & & & & \\
\hline \multirow{4}{*}{$\begin{array}{l}\text { Other } \\
\text { business }\end{array}$} & $1995 / 7$ & 5,651 & 6,013 & $6 \%$ \\
\hline & $2000 / 2$ & 5,049 & 6,269 & $24 \%$ \\
\hline & $2005 / 7$ & 5,067 & 5,490 & $8 \%$ \\
\hline & $2008 / 10$ & 4,656 & 5,969 & $28 \%$ \\
\hline & & & & \\
\hline \multirow{4}{*}{$\frac{\text { All other }}{\text { [personal] }}$} & $1995 / 7$ & 7,819 & 9,293 & $19 \%$ \\
\hline & $2000 / 2$ & 5,971 & 8,060 & $35 \%$ \\
\hline & $2005 / 7$ & 5,993 & 7,764 & $30 \%$ \\
\hline & $2008 / 10$ & 6,050 & 6,904 & $14 \%$ \\
\hline & & & & \\
\hline \multirow{4}{*}{ All use } & $1995 / 7$ & 18,178 & 22,157 & $22 \%$ \\
\hline & $2000 / 2$ & 15,161 & 19,603 & $29 \%$ \\
\hline & $2005 / 7$ & 14,478 & 19,212 & $33 \%$ \\
\hline & $2008 / 10$ & 14,074 & 18,350 & $30 \%$ \\
\hline
\end{tabular}

Table 3: Driving mileage per company car driver, by journey purpose and whether employer also provides free fuel for personal use

\section{Who uses company cars?}

Table 4 shows how the personal income levels of company car drivers compare to those of other adults, over time. It is unsurprising that company car owners tend to have higher incomes; this is the group most likely to be in an occupation where a company car is available, and the tax advantages of a company car are more substantial for people in higher-income tax brackets.

What is more unexpected is that, in real terms, the incomes of company car owners have dropped since around 2000/2, while for all other adults mean incomes increased until the recession and then fell by one per cent versus $7 \%$ for company car owners. Some of this latter effect will be due to the decreasing prevalence of company car ownership (see Table 1): fewer high-income people with a company car means that more of them will be included in the 'all other adults' category. The fact that real incomes for company car owners have fallen seems to indicate that company car ownership has fallen most amongst the wealthier.

$1995 / 7$

$2000 / 2$

$2005 / 7$

$2008 / 10$
Drivers of company cars

$£ 41,000$

$£ 42,200$

$£ 39,600$

$£ 37,000$

\section{All other adults}

$£ 14,100$

$£ 16,600$

$£ 17,300$

$£ 17,100$ 
This is confirmed when we look at differences in occupational composition over time. Figure 6 shows how company car ownership varies by the socio-economic group (SEG) of workers. The highest ownership levels are amongst occupations that fall within the 'employer/manager' and 'professional' classes, both of which are associated with higher than average incomes; in the mid1990s more than one in five of the former and one in eight of the latter had a company car. But between 1995/97 and 2008/10 the rate of company car ownership has fallen most sharply amongst these classes - to the point where employer/managers in 2008/10 had a similar rate of ownership to professionals in 1995/97, and professionals now have a rate which is similar to the non-manual and self-employed non-professional groups.

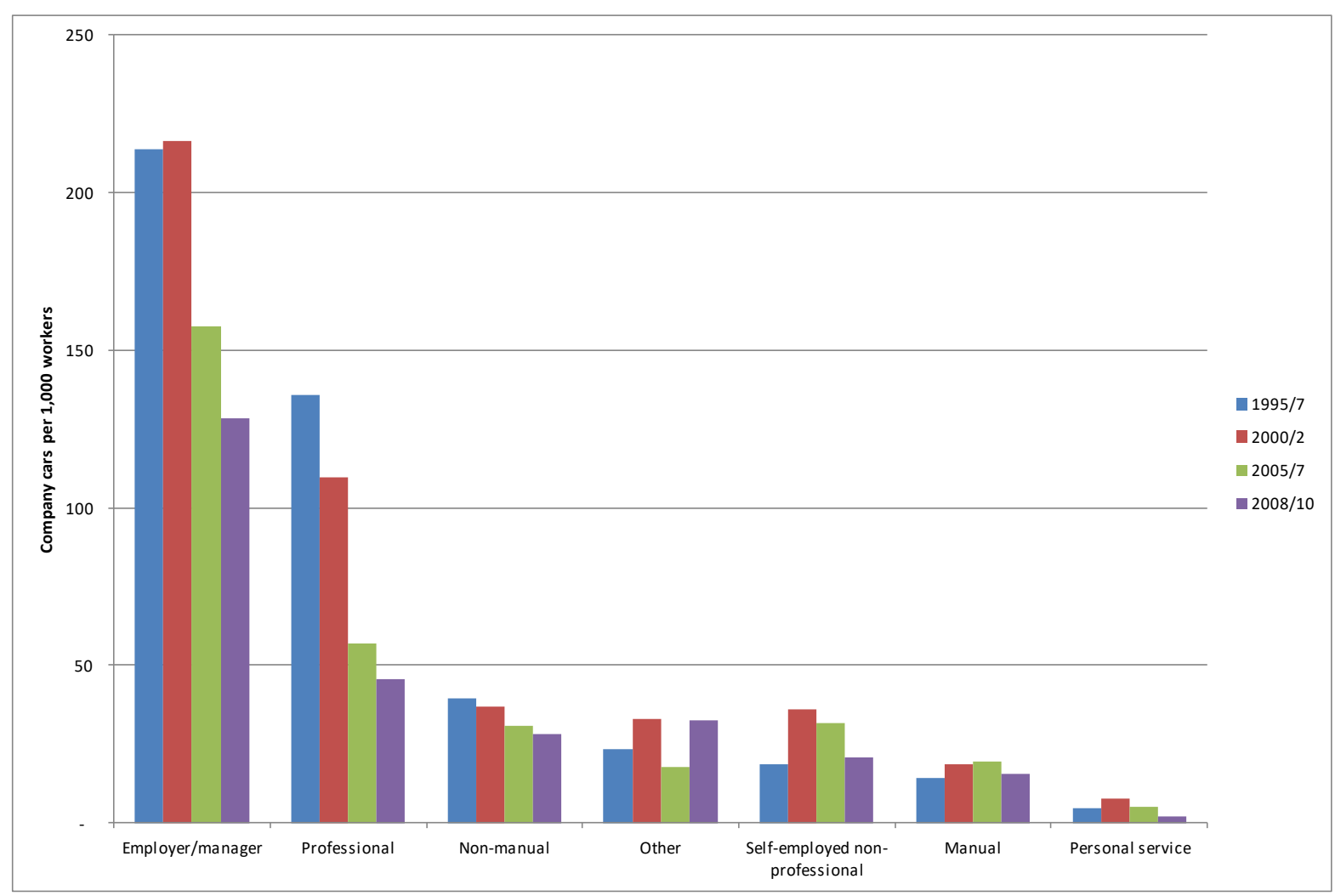

Figure 6: Company car ownership by socio-economic group (reproduced from Le Vine and Jones 2012)

Figure 7 looks in more detail at company car mileage by age and gender, expanding on some of the information in Figure 4. Here it can be seen that company car use has predominantly been a middleage-male phenomenon. As a consequence, the fall in company car use has predominantly taken place amongst men, such that in relative terms women now account for a much larger proportion of company car travel than in the 1990s. In 1995/7 men drove more than seven miles in company cars for each one that women drove, this ratio in mileage fell to under $4: 1$ in the most recent data (2008/10). 
There has also been an aging of company car drivers. The age of the average company-car-driver, weighted by vehicle-kms, increased from 41.5 years in 1995/7 to 44.2 years in 2008/10. This was about a third (32\%) faster than the aging of Britain's adult population, but a third (32\%) slower than the increase in the average driver age of personal car vehicle-kms.

There have been divergent trends in the spatial distribution of company cars, which not surprisingly breaks down differently for the Greater South East of England (the London, South East, and Eastern NUTS1 regions) and the rest of Britain. In 1995/7 the prevalence of company cars (cars per 1,000 population) was 32\% greater in the Greater South East than the rest of Britain; but by 2008/10 this had reversed and it was 6\% lower in the Greater South East than elsewhere. Indeed, the drop in company car activity by Londoners was sharp enough to be a major contributor to London's falling traffic levels in recent decades - something which had not previously been recognised (see Table 5). (This excludes the effects of Londoners driving outside of London, and of non-Londoners driving within London). Company car mileage by London residents dropped an average of 204 miles per resident between 1995/7 and 2005/7, compared to a drop of 154 miles per person in personal cars. Interestingly the data show mileage in company cars to have risen in the recession-affected years, though at a low mileage level (134 miles per London resident per year in 2008/10 v. 111 in 2005/7; this difference is not statistically significant, $p=0.45$ ).

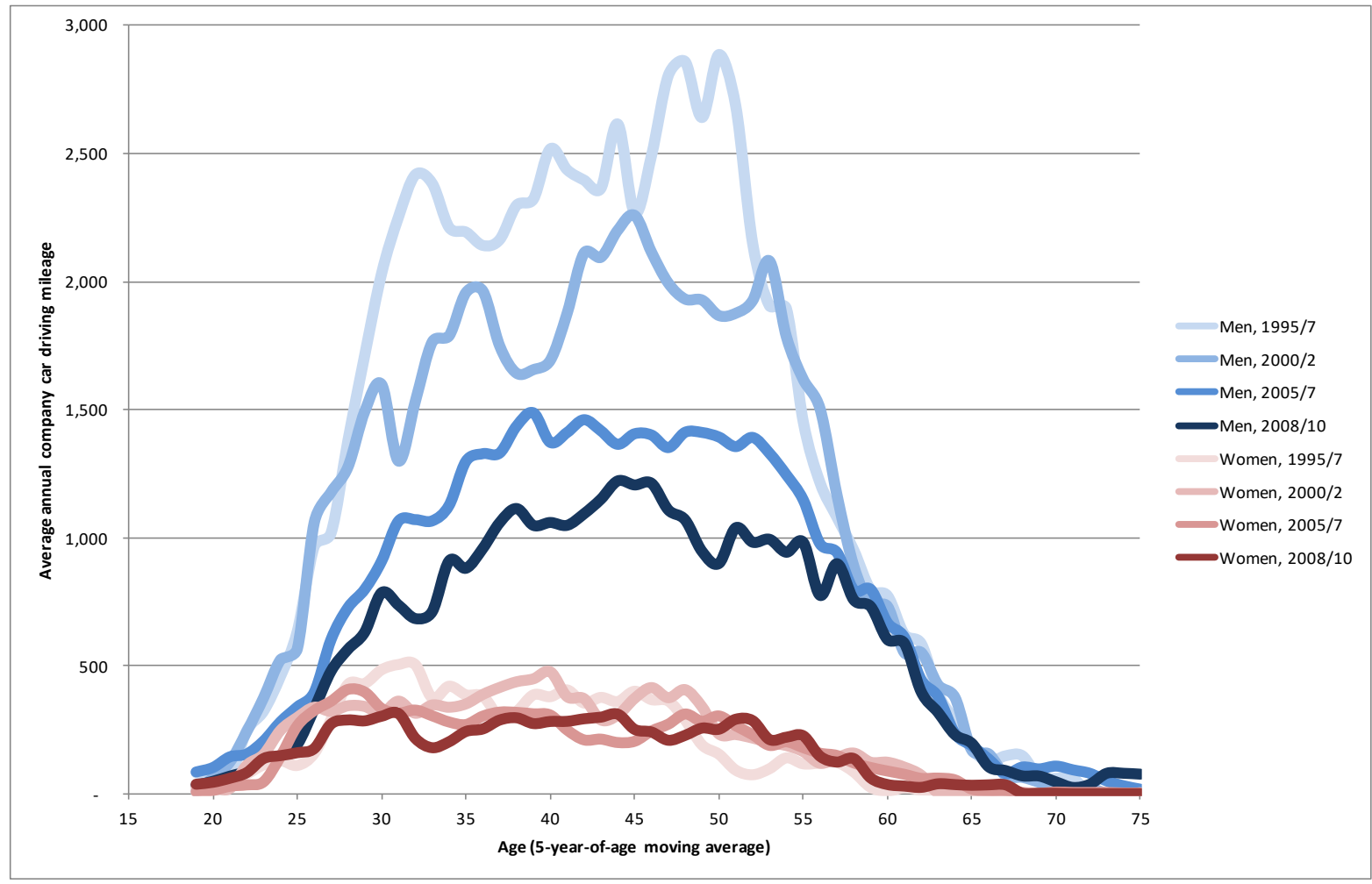

Figure 7: Company car driving mileage per capita, by age and sex

$\begin{array}{ccc}\text { Personal cars } & \frac{\text { Company }}{\text { cars }} & \frac{\text { Non-household }}{315}\end{array}$

Average driving mileage per London resident per year, 1995/7 
Average driving mileage per London resident per year, 2000/2

Average driving mileage per London resident per year, 2005/7

Average driving mileage per London resident per year, 2008/10

Difference in mileage (1995/7 to 2005/7)

Difference in mileage, in percentage terms (1995/7 to $2005 / 7)$

Percentage of reduction in car driving mileage (1995/7 to $2005 / 7)$

Table 5: Trend in car driving mileage per resident of London by type of car ownership: personal car, company cars, and non-household cars

Figures 8 and 9 (for men and women, respectively) look at the total annual car driving mileages of four groups of people from across Great Britain who commute or make business trips on at least two days in their diary week by any mode of transport. Each figure distinguishes between four population groups: London residents travelling for commuting/business; non-London residents who come into London for commuting/business purposes; other workers who do not visit London but report commuting/business trips; and, all other adults.

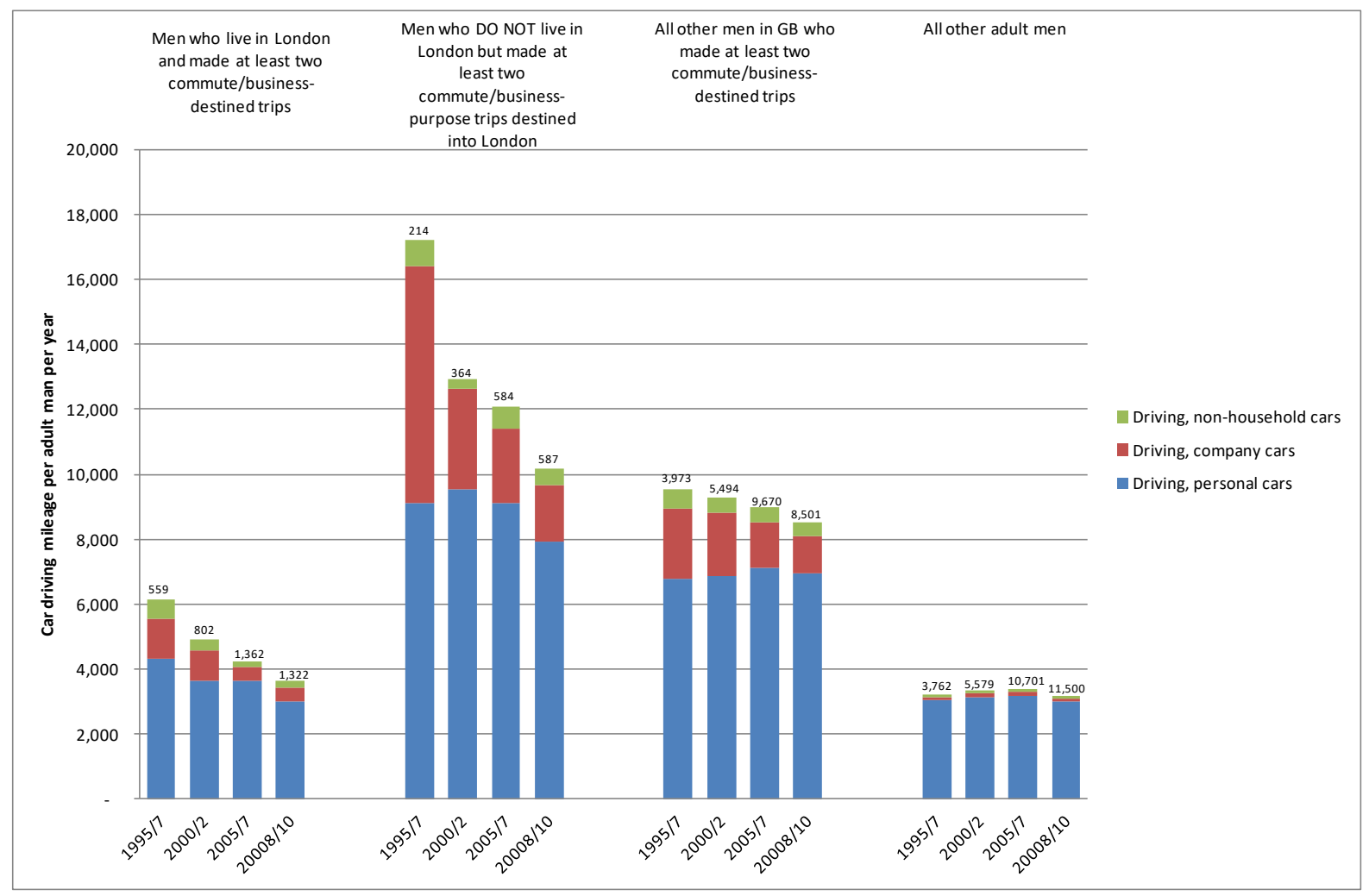

Figure 8: Car driving mileage per man, disaggregated by type of car ownership and home- and work-related locations, unweighted sample sizes shown above bars (reproduced from Le Vine and Jones 2012) 
In all four groups men have higher average annual car driver mileages than women, but in many cases the time trends are different. The lowest annual car-driving mileages are among adults who do not make at least two commuting or business trips per week (by any mode); this group shows a slight increasing trend in driving mileage over time for both sexes, but virtually none of this is in a company car. The next lowest annual mileage is by economically-active London residents; here, men show a reduction over time that is largely due to reduced mileage in company cars and to a smaller degree due to non-household cars; the reduction for females is much smaller - but their annual mileage is still not much more than half of the comparable group of men.

In aggregate, the annual car mileage by employed people who do not visit London has remained steady over the ten-year period, but this is made up of a slight decline over time among males offset by a slight increase among females. For males, a reducing mileage in company cars is partly offset by a growth in mileage in private cars.

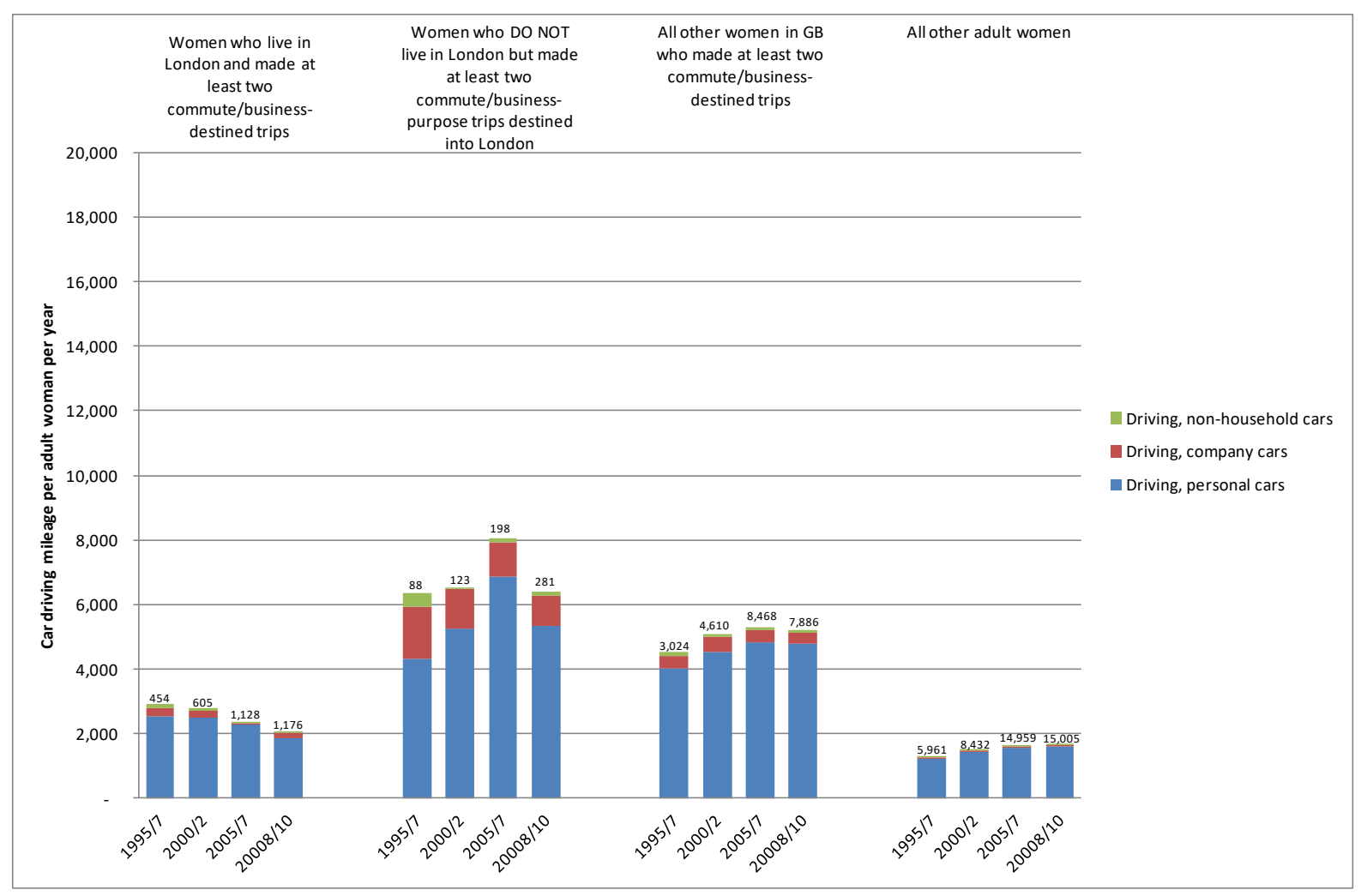

Figure 9: Car driving mileage per woman, disaggregated by type of car ownership and home- and work-related locations, numbers shown above bars are unweighted sample sizes (reproduced from Le Vine and Jones 2012)

The highest annual car mileages are to be found among adults living outside London who visited it on two or more occasions in their NTS diary week for commuting/business-related purposes. Here we observe a large reduction in car mileage by men - down from 17,210 to 12,067 miles between 1995/7 and 2005/7; most of this reduction is due to less company car mileage and occurred between $1995 / 7$ and 2000/2, before the introduction of congestion charging in central London. Women in 
this group, on the other hand, saw an overall increase in their average driving mileage (up from 6,329 to 8,060 miles per year) despite reductions in their company car mileage. Most of this increase occurred between 2000/2 and 2005/7, and indeed the effect of the recession seems to have been a major reduction in driving mileage for this female group, to just under their level in $2000 / 2$.

\section{Substitution between company car mileage and other vehicles or modes}

An important question raised by the observed sharp and sustained drop in company car travel is whether this mobility has simply been foregone (and if so to what degree), or whether it is being manifested in different forms of travel. It is worth noting that there is quantitative evidence suggesting that prospective changes in British company car taxation policy would be the single most effective pricing measure to increase public transport usage (Balcombe et al. 2004).

Here we briefly investigate two potential substitution effects: between company and private car travel, and between company car and rail mileage. Bearing in mind that this analysis is using a repeated cross sectional survey and not a panel survey, so that only group average results can be reported - with resulting limitations in establishing causality.

Figures 10 and 11 plot changes in average company car mileage between 1995/97 and the three later time periods (2000/02, 2005/07 and 2008/10), against changes in average personal car mileage for the British adult employed population as a whole, and for those in various occupations. Figure 10 shows the relationship for men and Figure 11 for women. Each figure is divided into four quadrants, of which the lower right (i.e. reduced company car mileage, increased private car mileage) would suggest some substitution, at least at an aggregate level. 


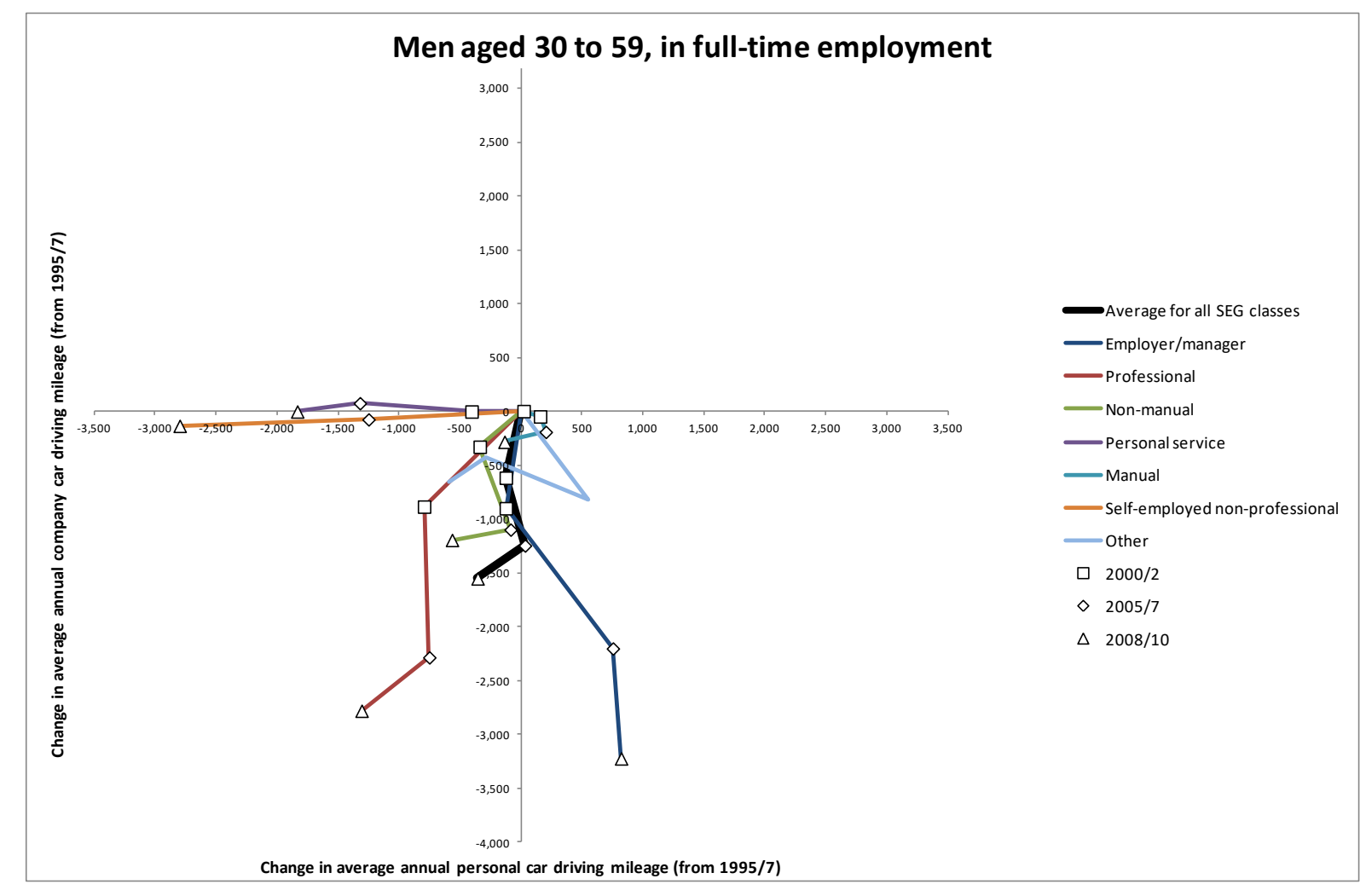

Figure 10: Changes in company and private car driving mileage over time for men, by employment category

In the case of men, and looking first at all employed groups (thick black line), Figure 10 shows that there was no net substitution between company and private car mileage up to 2005/07, since when both types of mileage have reduced at a similar rate. Professionals have shown strong declines in both company and private car mileage. In contrast, there is strong and consistent evidence of substitution between company and private car mileage among the 'Employer/manager' group; over the period $1995 / 97$ to $2008 / 10$, while company car mileage fell on average by 3,222 miles, private car mileage increased by 821 miles - a 4:1 substitution.

As was previously evident from Figure 4, the picture for employed women is very different (see Figure 11). Here both company car and private car mileage have been increasing for most groups. Again, the major exception has been among the 'Professional' group, where company car mileage has dropped significantly - suggesting that the nature of the class described as 'Professional' has probably changed substantially in nature in recent decades. 


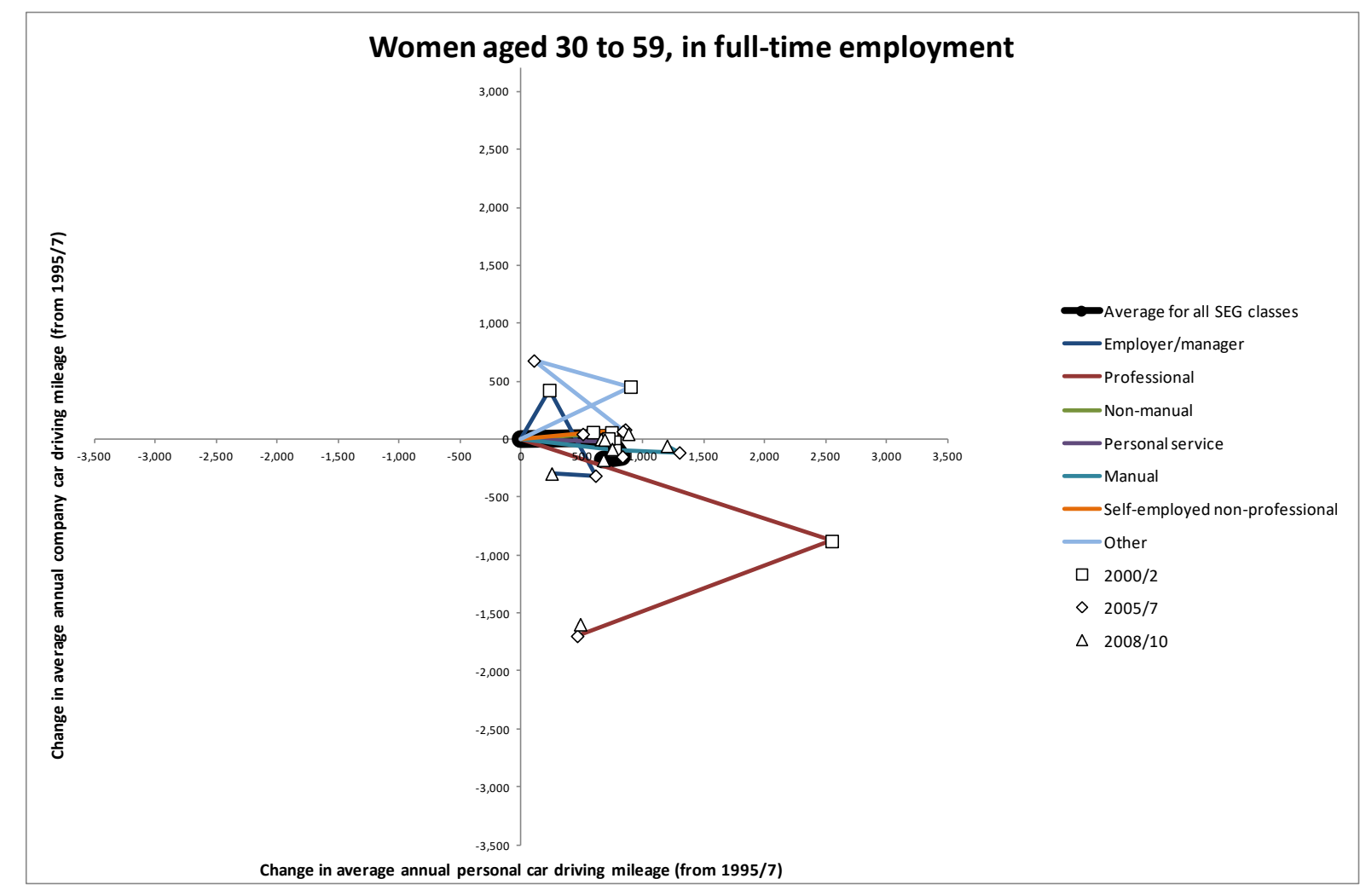

Figure 11: Changes in company and private car driving mileage over time for women, by employment category

There is also some evidence of a shift from company car to rail travel (Le Vine and Jones 2012). Figure 12 looks at this issue by plotting, for each age/gender group, changes in company car mileage (from 1995/7 to 2005/7) on one axis against the growth in mileage by rail for the same age/gender groups on the other axis, for several major journey purposes.

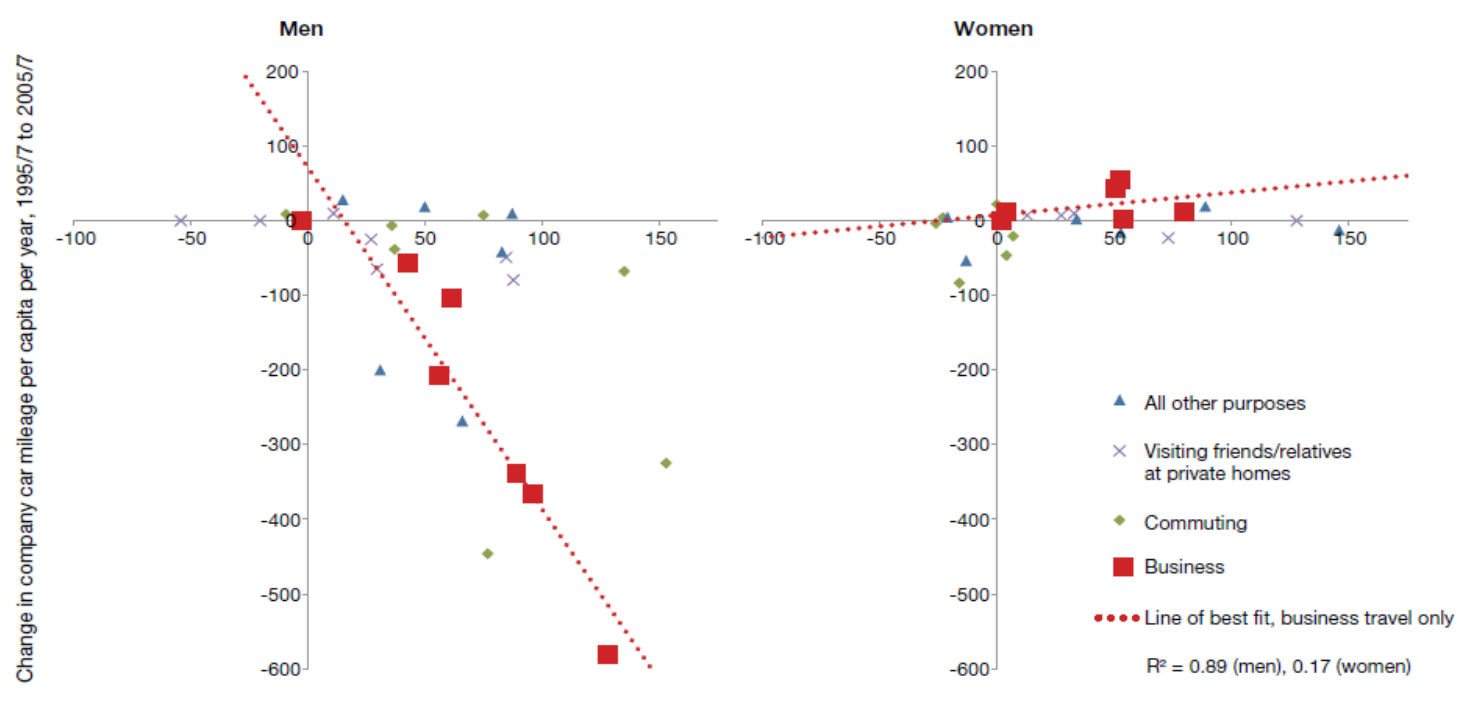

Change in National Rail mileage per capita per year, 1995/7 to 2005/7

Figure 12: Changes in company car business mileage plotted against changes in rail business mileage, by age and sex groups. 
Here we see a very strong negative relationship for men's business mileage (with an $r^{2}$ value of 0.89 ) but for women on average a small growth in business mileage, both in company cars and by rail. For men, the line of best fit has roughly a -4:1 slope: so that for each mile of reduction in company car use for business travel, roughly a quarter-mile seems to have shown up as increased rail use. There is a somewhat weaker relationship for men (but, again, not for women) between company car and rail mileage for the visiting-friends-and-relatives-at-private-homes journey purpose; here the slope is roughly $-1: 2$, with an $r^{2}$ value of 0.64 . Note that this analysis is at the group, not the individual level, and takes a cross sectional approach, so is indicative rather than definitive.

\section{Discussion and conclusions}

Although much work remains to be done to understand the influence of public policy and other factors on the stabilisation of per-capita car travel in Britain, it is hoped that this study has provided a useful contribution and will encourage other researchers to investigate whether there is evidence of analogous effects relating to company car use in other OECD countries.

This paper has shown that the sharp decline in company car use among men has been an important and previously under-appreciated component of the trends in car travel in Britain since the 1990s largely off-setting an increase in car driving mileage among women, and so contributing significantly to the observed 'Peak car' effect. The distinction between personal and company cars provides a fresh perspective on the stabilisation in per-capita car driving levels prior to the onset of the current recession. In London, for instance, the falling company car usage has been a larger contributor than the drop in personal car usage to the decline in overall car driving mileage per capita.

We have found differences in the size of changes in company car use according to occupational category, with particularly large reductions among those classified as 'Professionals' - this is the only category where women have also experienced significant reductions. There is limited evidence of substitution of company car mileage; among males, only the 'Employer/managers' group has significantly increased their private car mileage. More generally, rail use seems to have increased alongside reductions in company car mileage.

It is clear that this decline in company car ownership and use cannot continue indefinitely; in 2008/10 levels of company car ownership had already dropped by over $40 \%$ since the mid-1990s. During the 1990s and 2000s it has helped to offset the growth in average car mileage by women; which raises the question of whether, once the trend of a decreasing company car mileage has run its course, average mileage will start to rise again. Preliminary published results from the 2011 NTS survey (DfT 2013) show that in 2010 and 2011 there have been small year-on-year increases in car mileage per person, despite the continuing recession, but this table does not distinguish between company and private cars - and several more years' data would be required to assess with confidence whether the apparent 'Peak Car' effects has been replaced by further growth. It should be noted that, as of 2010, personal car use remained below the pre-recession peak, and that this is likely to be true in 2011 as well when the personal/company-car breakdown is published.

We have shown that this sharp, historical fall in company car usage has been associated with structural changes in tax policy during the same time period - but this cannot be the full explanation 
for the decline in male car driving mileage, as for some groups of men their average private car mileage has declined as well. Over the same period there have been significant increases in fuel prices, a gradual increase in car restraint policies (from parking restrictions to area access restrictions and congestion charging in London), a levelling off in average door-to-door car speeds following decades of growth, heavy investment in the national rail network, and substantial improvements to public transport in many urban areas. All of these factors are likely to have had a collective significant impact on patterns and levels of car use in Great Britain.

We also cannot, on the evidence at hand, discount the possibility that these potential policy impacts are confounded with contemporaneous changes in attitudes towards company cars (e.g. the rise of the 'corporate social responsibility' agenda), and towards car use in general - helped by 'behaviour change' programmes. It is also quite possible that the [relative] functional value of [various types of] company cars has not been completely stable over time, due to wider economic and/or technological trends. Whilst these possibilities cannot be excluded, the fact that the outcome (a strong decline in company car usage) coincides temporally with tax incentives is strongly suggestive - and, indeed, is a more convincing linkage than empirical evidence that serves as the basis for much real-world policy-making.

One lesson of this research is that the design of travel surveys has a strong influence on what can be explored: the NTS is the only British data set that collects multi-day data, and the only one which associates each car trip with the details of the vehicle used. Without this explicit linkage it would not have been possible to have uncovered the significance for aggregate trends in car use of company car ownership and usage - indeed, this is probably the main reason why previous research, using other data sets, was not able to identify such a relationship.

The apparent impacts on levels of car use of employers providing staff with 'free fuel' (which functions as fuel paid for with pre-tax, rather than post-tax, earnings) - before it started to incur a significant tax charge - may have implications for how electric vehicles will affect mobility patterns in the future, given that marginal operating costs could be much lower for electric vehicles than for internal-combustion engine vehicles.

Future research is needed along several lines of enquiry. First, properly establishing the distinction between company cars that are essential for performing business functions and those that are provided as simply a fringe benefit for senior staff is necessary, as is identifying whether there have been divergent trends in use of these different kinds of company car. This will help in understanding how company car travel could trend in the future. A related point is that traffic forecasting methods require updating to take into account the unique characteristics of company cars; it is clearly a different regime of car access than owning a personal car.

This study did not directly address two important research questions: 1) What are the mobility patterns of people who do not now have a company car but in years past would likely have had one? and 2) What impact does the presence of a company car within a household have on the mobility of other household members besides its main driver? The former would be best addressed with a panel data set, while the latter could be analysed using the NTS data sets used in this study.

A linked issue is the possibility of path dependency associated with past company car ownership. It is entirely plausible that having a company car which is then handed back or taken away by one's 
employer is associated with different long-term mobility outcomes than never having had a company car. Stokes (2012) has shown that acquiring a driving licence after one's teenage years is associated with lower-than-average levels of car use in later life; it is plausible that, for instance, past experience with owning and using a company car might have the opposite effect, though innovative data sources will be needed to investigate such issues.

Finally, this study did not distinguish between company car usage and potential competing options: in particular, using a private car and claiming a business mileage rate, or having some form of light van or land rover/jeep (whose personal/company ownership status is not asked in the British NTS). Van usage, in particular, is an issue of growing relevance to overall traffic levels on Britain's roads, and future research is needed to understand the determinants of the differences in how cars and vans are used, particularly at the margin as the light van fleet is growing rapidly.

\section{Acknowledgements}

This paper draws heavily on parts of the study On the Move: Making sense of car and train travel trends in Britain, sponsored by the Independent Transport Commission, Office of Rail Regulation, RAC Foundation, and Transport Scotland (Le Vine and Jones, 2012). The authors wish to thank the sponsors corporately and the members of the Steering Committee as individuals. Gratitude is also due to the Department for Transport's National Travel Survey team and to HM Revenue \& Customs' Knowledge, Analysis and Intelligence team, for providing data and advice. Any errors are the exclusive responsibility of the authors.

\section{References}

Balcombe, R., Mackett, R., Paulley, N., Preston, J., Shires, J., Titheridge, H., Wardman, M., White, P. (2004): The demand for public transport: A practical guide. Transport Research Laboratory Report \#TRL593.

Bureau of Infrastructure, Transport and Regional Economics (BITRE), (2012), Traffic Growth: Modelling a Global Phenomenon, Report 128, Canberra ACT.

Canada Revenue Agency (CRA) (2012) http://www.cra-

arc.gc.ca/tx/bsnss/tpcs/pyrll/bnfts/tmbl/clcltbnft-eng.html. Accessed 15/12/2012.

Department for Transport (DfT) (2012a): Table VEH0252: Cars registered for the first time by keepership, Great Britain, annually: 2001 to 2011.

Department for Transport (DfT) (2012b): Table NTS0305: Average distance travelled by mode: Great Britain, 1995/97 to 2011.

Goodwin, P. (2012a) Three views on 'Peak Car'. World Transport Policy \& Practice, 17.4, 8-17.

Goodwin, P. (2012b). 'Peak Car': An overview. Presentation to Transport Statistics Users Group, London, 25/4/12.

Great Britain. Finance Act (1976): Elizabeth II. London: The Stationery Office. 
Her Majesty's Revenue and Customs (HMRC) (2012a) Benefits in kind statistics, July 2012. Accessed 15/12/2012 at: http://www.hmrc.gov.uk/statistics/tax-benefits/statistics.pdf.

Her Majesty's Revenue and Customs (HMRC) (2012b) Forthcoming changes to the car benefit rules. Accessed 15/12/2012 at: http://www.hmrc.gov.uk/cars/rule-changes.htm.

Kuhnimhof et al (2012) Men Shape a Downward Trend in Car Use among Young Adults-Evidence from Six Industrialized Countries, Transport Reviews, 32 (6), 761-779.

Le Vine. S. and Jones, P. (2012). On the Move: Making sense of car and train travel trends in Britain. RAC Foundation, London.

Macharis, C., and De Witte, A. (2012) The typical company car user does not exist: The case of Flemish company car drivers. Transport Policy, 24, 91-98.

Metz, D. (2012) Demographic determinants of daily travel demand. Transport Policy, 21, 20-25.

Naess-Schmidt, S., Winiarczyk, M. (2009) Company car taxation: Subsidies, welfare, and environment. European Commission Taxation Paper No. 22.

Rofique, J., Humphrey, A., Pickering, K., Tipping, S. (2011) National Travel Survey 2010 Technical Report. Prepared for Department for Transport. London.

Stokes, G. Has car use per person peaked? Age, gender and car use. Presentation to Transport Statistics Users Group, London, 25/4/12.

van den Berg, P., Arentze, T., and Timmermans, H. (2013) A path analysis of social networks, telecommunication, and social activity-travel patterns. Transport Research Part C, 26, 256-268. 